\title{
Bell Pepper (Capsicum annum L.) Crop as Affected by Shade Level: Microenvironment, Plant Growth, Leaf Gas Exchange, and Leaf Mineral Nutrient Concentration
}

\author{
Juan Carlos Díaz-Pérez ${ }^{1,2}$ \\ Department of Horticulture, University of Georgia, 2360 Rainwater Road, \\ Tifton, GA 31793-5766
}

Additional index words. Capsicum annum, shade house, heat stress, plasticulture, chlorophyll index, climate change

\begin{abstract}
Use of shading nets helps ameliorate heat stress of vegetable crops. This study evaluated the effects of shade level on microenvironment, plant growth, leaf gas exchange, and mineral nutrient content of field-grown bell pepper crop. Bell pepper cultivars Camelot, Lafayette, Sirius, and Stiletto were grown at $0 \%, 30 \%, 47 \%, 62 \%$, and $80 \%$ shade levels. Photosynthetically active radiation and air, leaf, and root zone temperatures decreased as shade level increased. Despite having increased plant leaf area, there was increased soil water content with increased shade level, indicating reduced soil water use. With increased shade level, the total plant leaf area, individual leaf area, and individual leaf weight increased, whereas leaf number per plant and specific leaf weight decreased. In contrast to non-normalized chlorophyll index (CI) values, CI normalized by specific leaf weight were related to leaf nitrogen $(N)$ and increased with increased shade level. Net photosynthesis and stomatal conductance $\left(g_{\mathrm{S}}\right)$ decreased and leaf transpiration increased with increased shade level, particularly above $47 \%$ shade level. Leaf concentrations of $N$, potassium $(\mathrm{K})$, calcium $(\mathrm{Ca})$, magnesium (Mg), manganese (Mn), sulfur (S), aluminum (Al), and boron (B) increased with increased shade level. Relatively few differences in plant growth, leaf gas exchange, and leaf mineral nutrient concentrations were observed among cultivars. In conclusion, morphological changes such as taller plants and thinner and larger leaves likely enhanced light capture under shaded conditions compared with unshaded plants. High shade levels reduced leaf temperature and excessive leaf transpiration but resulted in reduced leaf photosynthesis. Thus, moderate shade levels (30\% and $47 \%)$ were the most favorable for bell pepper plant growth and function.
\end{abstract}

Bell pepper (Capsicum annum L.) is an important crop in many parts of the world and is typically grown in open fields on plastic film mulch. In Georgia, bell pepper is grown in the spring and fall on $\approx 1860$ ha and has a value of $\$ 50$ million. In the spring, bell peppers are typically planted from March to April and harvested from May to early July. Increased temperatures occurring in late

Received for publication 9 Dec. 2011. Accepted for publication 6 Dec. 2012.

Financial support provided by the Georgia Agricultural Experiment Stations.

I thank Dr. John Silvoy and Jesús Bautista Popoca for their invaluable technical support. I sincerely appreciate the thorough review of the manuscript by John Ruter, Patrick Conner, Karla Gabriela Díaz-Hernández, and the anonymous reviewers.

Mention of trade names in this publication does not imply endorsement by the University of Georgia of products named nor criticism of similar ones not mentioned.

${ }^{1}$ Professor.

${ }^{2}$ To whom reprint requests should be addressed; e-mail jcdiaz@uga.edu. spring and early summer reduce bell pepper yields and increase incidences of fruit physiological disorders such as blossom-end rot and sunscald causing significant loss (Olle and Bender, 2009; Taylor and Locascio, 2004). High temperatures induce flower and fruit abortion in bell pepper (Deli and Tiessen, 1969; Dorland and Went, 1947).

Shading nets are used in tropical and subtropical countries for vegetable production (Allen, 1975; Castellano et al., 2008; El-Aidy et al., 1993; Ilic et al., 2012; Kittas et al., 2012; Rylski and Spigelman, 1986). Shading nets were used since the early-1900s to the 1960s in the United States for tobacco (Nicotiana tabacum) and vegetable production in the northeast and southeast regions (Allen, 1975; Duggar, 1903; Young, 1961). There is, however, little information on use of shading for vegetable production in the southeast United States over the past 40 years (Boyhan et al., 2008; Roberts and Anderson, 1994; Russo, 1993). Studies in Israel report that shading increases plant growth and yield in bell pepper (Rylski and Spigelman, 1986). Shading also reduces water requirements and increases irrigation water use efficiency in peppers (Moller and Assouline, 2007). This study evaluated the effects of shade level on the bell pepper crop microenvironment, plant growth, leaf gas exchange, and mineral nutrient content.

\section{Materials and Methods}

The study was conducted at the Horticulture Farm, Univ. of Georgia, Tifton, GA, during the Spring-Summer seasons of 2009 and 2010. The soil was a Tifton Sandy Loam (a fine loamy-siliceous, thermic Plinthic Kandiudults) with a $\mathrm{pH}$ of 6.5 . Before laying mulch with a mulch-laying machine, the soil was fertilized with $\mathrm{N}$, phosphorus $(\mathrm{P})$, and $\mathrm{K}$ at 90, 39.6, and $83 \mathrm{~kg} \cdot \mathrm{ha}^{-1}$, respectively, using $10 \mathrm{~N}-10 \mathrm{P}-10 \mathrm{~K}$ granular fertilizer. At the same time, plastic film mulch [silver on black, lowdensity polyethylene with a slick surface texture, $1.52 \mathrm{~m}$ wide and $25 \mu \mathrm{m}$ thick (RepelGro; ReflecTek Foils, Inc., Lake Zurich, IL)] was laid, drip irrigation tape $[20.3-\mathrm{cm}$ emitter spacing and a $8.3-\mathrm{mL} \cdot \mathrm{min}^{-1}$ emitter flow (Ro-Drip; Roberts Irrigation Products, Inc., San Marcos, CA)] was placed $5 \mathrm{~cm}$ deep in the center of the bed.

The experimental design was a randomized complete block with four replications and 20 treatments (five shade $\times$ four cultivar combinations). Shading treatments were: $0 \%$, $30 \%, 47 \%, 63 \%$, and $80 \%$ reduction of photosynthetically active radiation (PAR; according to the manufacturer). The cultivars were Camelot (Seminis, Oxnard, CA), Lafayette (Siegers Seed Co., Holland MI), Sirius (Siegers Seed Co., Holland MI), and Stiletto (Rogers, Boise, ID).

Bell pepper transplants were produced in a greenhouse using peat-based medium (Pro-Mix, Quakertown, PA) and polystyrene 200 -cell $(2.5 \times 2.5$-cm cell $)$ trays. The length of experimental plot was $3.3 \mathrm{~m}$ and plants were established on individual raised beds $(6 \times 0.76 \mathrm{~m}$ with raised beds formed on $1.8-\mathrm{m}$ centers). Six-week-old bell pepper transplants were planted on 15 Apr. 2009 and 23 Apr. 2010 on two rows per bed with a $30-\mathrm{cm}$ separation between plants and $36-\mathrm{cm}$ separation between rows. Approximately $240 \mathrm{~mL}$ of starter fertilizer solution (555 ppm N; 821 ppm P; 0 ppm K) was applied directly to the base of each transplant. Starting 3 weeks after transplanting, plants were fertilized weekly through the drip system.

Shade nets [polypropylene black shade net (Baycor Industrial Fabric, Pendergrass, GA)] were supported with metallic cable and posts forming a pyramidal structure with the highest point at $\approx 2 \mathrm{~m}$ along the center of the bed. Shade nets were set 4 weeks after transplanting (12 May 2009 and 21 May 2010). The level of shading was verified by using quantum sensors of a ceptometer (SunFleck Ceptometer; Decagon Devices, Pullman, WA).

Plants were irrigated with an amount of water equivalent to $100 \%$ crop evapotranspiration $(\mathrm{ETc})$, which was calculated by multiplying the reference evapotranspiration (ETo) by the crop factor (dependent on the 
crop stage of development). Water was applied when cumulative ETc was $1.2 \mathrm{~mm}$, which corresponded to every $\approx 2$ to $3 \mathrm{~d}$ in mature plants (mean ETo was 5 to $6 \mathrm{~mm} \cdot \mathrm{d}^{-1}$ ). Weather data (air temperature, ETo, and rainfall) were obtained from a nearby University of Georgia weather station (less than $300 \mathrm{~m}$ ).

Microenvironment. PAR under each shade treatment was measured at midday (1200 to $1500 \mathrm{HR})$, on clear days, using a ceptometer
(Decagon Devices, Inc., Pullman, WA) taking two readings per plot. Leaf temperature $\left(\mathrm{T}_{\text {leaf }}\right)$ was measured in each plot with an infrared thermometer gun (Spectrum Technologies, Plainfield, IL). PAR and $\mathrm{T}_{\text {leaf }}$ measurements were conducted on 6,11 , and 24 June and 3 July 2009; 8, 9, 17, and 24 June, 14 and 29 July, and 6 and 18 Aug. 2010.

Air temperature $\left(\mathrm{T}_{\mathrm{air}}\right)$ was measured with a temperature sensor located inside a
WatchDog data logger (Model 12001 Spectrum Technologies). The data logger was programmed to record readings every hour for each plot containing cv. Camelot. Rootzone temperature (RZT) was measured by determining soil temperature midway between plants within the row at $10 \mathrm{~cm}$ below the mulch and the soil surface. Root zone temperature was measured with copper-constantan thermocouples (Model 107; Campbell Scientific,
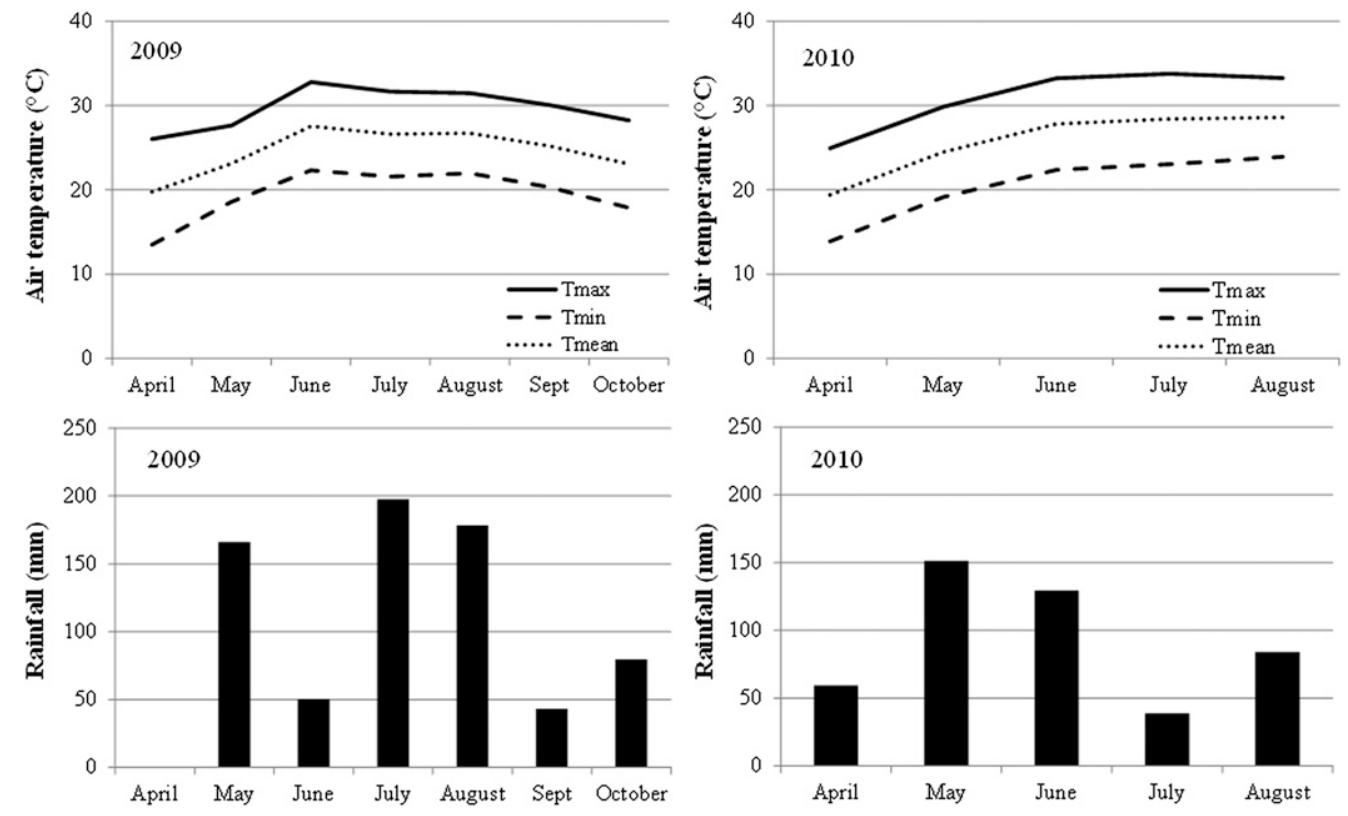

Fig. 1. Average monthly maximal, minimal, and mean air temperatures and monthly cumulative rainfall during the growing seasons in 2009 and 2010 . Weather data obtained from a nearby Univ. of Georgia weather station (less than $300 \mathrm{~m}$ ), Tifton, GA.
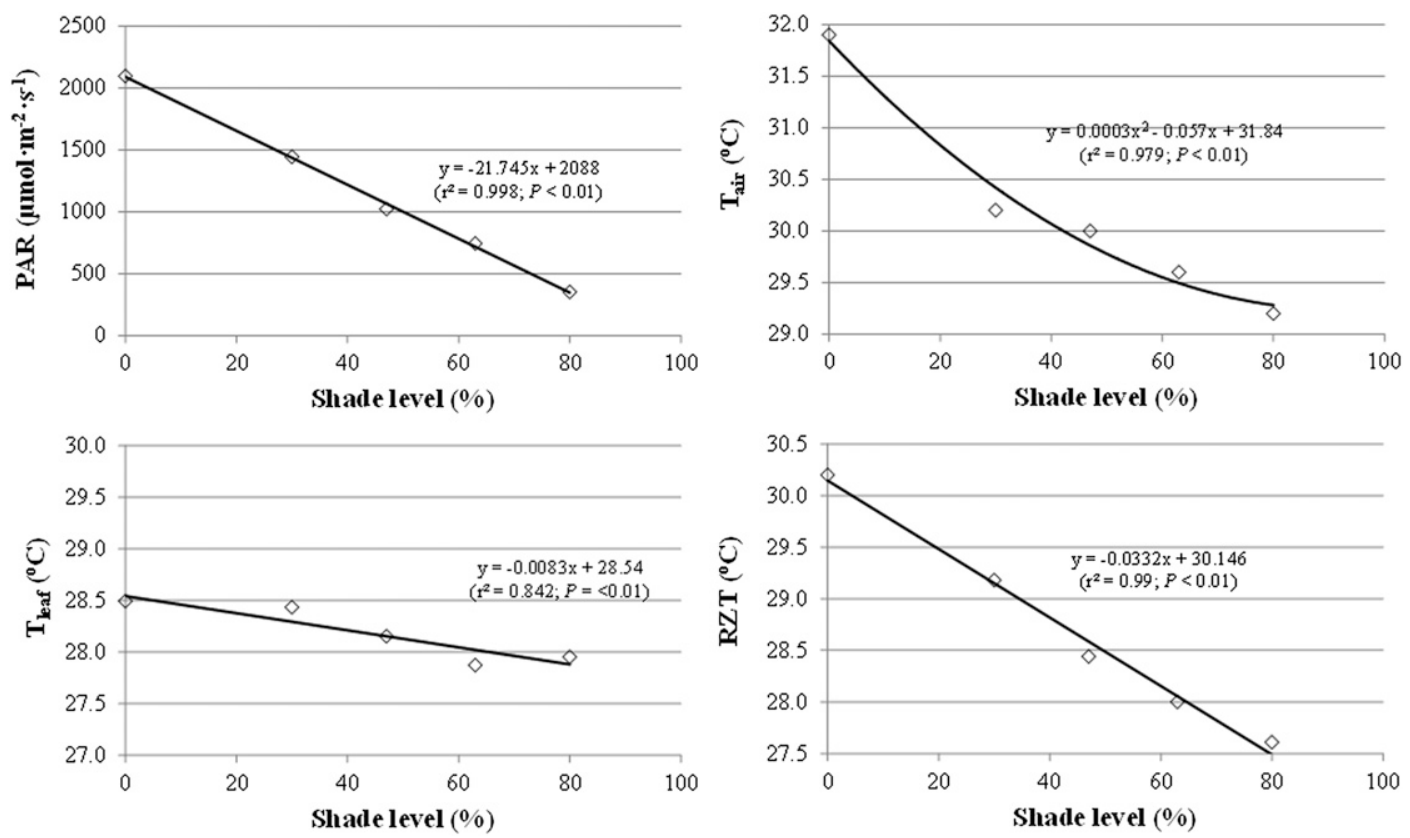

Fig. 2. Relationships of midday photosynthetically active radiation $(P A R)$, midday leaf temperature $\left(\mathrm{T}_{\text {leaf }}\right)$, mean air temperature $\left(\mathrm{T}_{\text {air }}\right)$, and mean root zone temperature (RZT) with shade level in bell pepper. PAR and $\mathrm{T}_{\text {leaf }}$ measurements conducted on 6, 11, and 24 June and 3 July 2009; 8, 9, 17 , and 24 June, 14 and 29 July, and 6 and 18 Aug. 2010. Tair and RZT measured during the period under shade (7 June to 15 Sept. 2009 and 28 May to 9 Aug. 2010), Tifton, GA, Spring of 2009 and 2010. 


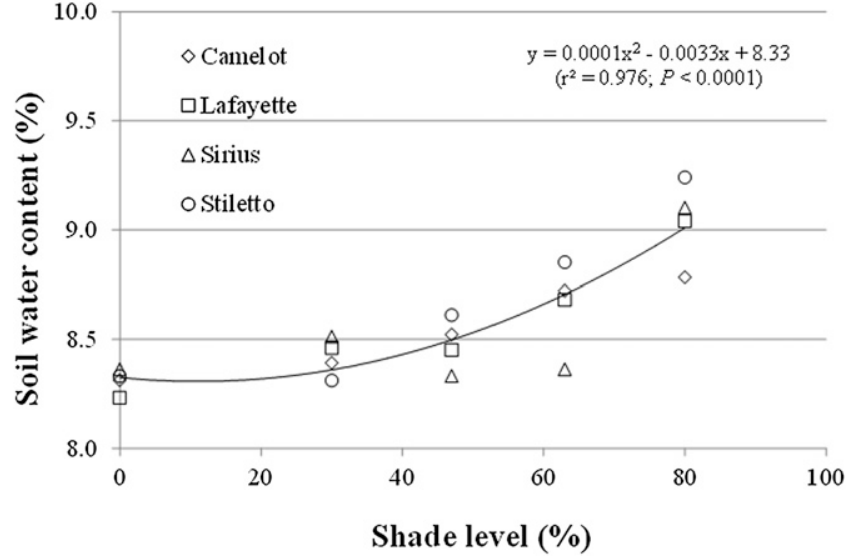

Fig. 3. Soil water content as function of shade level in bell pepper. Data from cultivars Camelot, Lafayette, Sirius, and Stiletto were pooled, Tifton, GA, Spring of 2009 and 2010.
Logan, UT) connected to a data logger (CR10X; Campbell Scientific) and an AM416 Relay Multiplexer (Campbell Scientific). Air temperature and RZT were measured during the period under shade ( 7 June to 15 Sept. 2009 and 28 May to 9 Aug. 2010) and were monitored only in cultivar Camelot as a result of a limited number of data loggers available.

Soil water content. Soil water content (volumetric) over the season was measured once every 2 to $3 \mathrm{~d}$ (three readings per experimental plot) with a portable time domain reflectometry (TDR) sensor (CS-620; Campbell Scientific). The two metallic $12-\mathrm{cm}$ rods of the TDR sensor were inserted vertically within the row between two plants.

Plant growth. Bell pepper plant height and stem diameter were measured weekly in
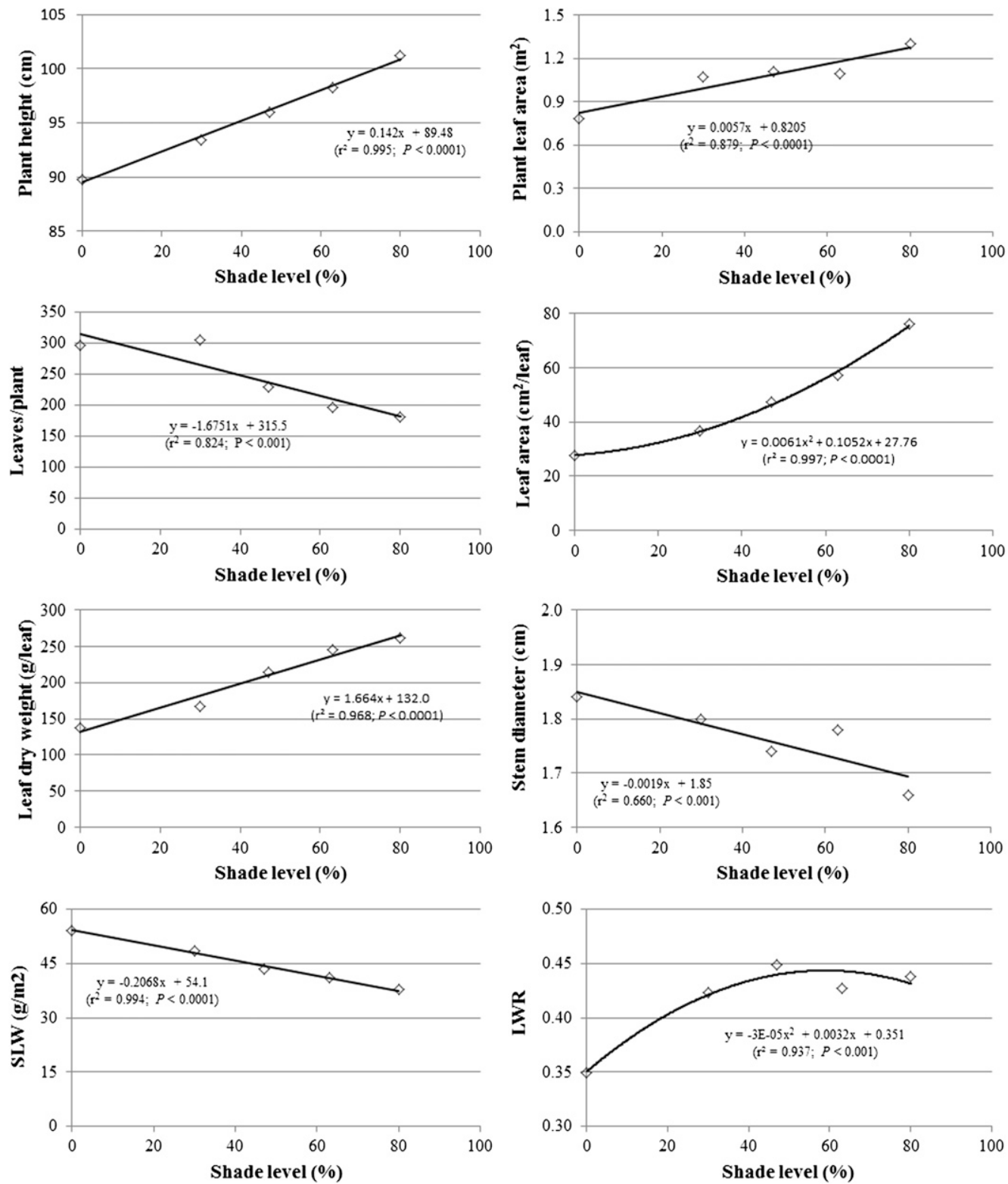

Fig. 4. Plant height, plant leaf area, leaf number per plant, individual leaf area and dry weight, stem diameter, specific leaf weight (SLW), and leaf weight ratio (LWR) in bell pepper as a function of shade level. Data from cultivars Camelot, Lafayette, Sirius, and Stiletto were pooled, Tifton, GA, Spring of 2009 and 2010 . 
three mature plants per plot. Plant leaf area, leaf number per plant, and individual leaf area were measured in two randomly selected mature plants per experimental plot excised at the soil level at the end of the season (30 Aug. 2010). Leaf area was measured with a leaf area meter (LI-3100C; LI-COR, Lincoln, NE). Plant samples were dried at $70{ }^{\circ} \mathrm{C}$ for several days until constant weight was obtained and leaf, stem, and vegetative top (leaf + stem) dry weights (DWs) of individual plants determined. For plant growth analysis, specific leaf weight (SLW) and leaf weight ratio (LWR) were calculated from leaf area and DW determinations as follows (Evans, 1972):

(1) $\mathrm{SLW}=$ leaf DW/leaf area

(2) LWR = leaf DW/vegetative top DW

Leaf chlorophyll index. CIs were determined twice a week over the season on six leaves per plot using a chlorophyll meter (Chlorophyll Meter SPAD-502; Minolta Co., Ltd., Ramsey, NJ).

Leaf gas exchange and photosystem II efficiency. Simultaneous measurements of leaf gas exchange (net photosynthesis, $g_{\mathrm{S}}$, transpiration, and internal $\mathrm{CO}_{2}$ concentration) and fluorescence determined as photosystem II (PSII) efficiency were made with an infrared gas analyzer (LI-COR 6400 IRGA with an integrated 6400-40 leaf chamber fluorometer; LI-COR, Inc., Lincoln, NE). PSII efficiency is the fraction of absorbed PSII photons used in photochemistry and is measured with a light-adapted leaf (LI-COR, 2003). Water use efficiency was calculated as the ratio between net photosynthesis and transpiration. Air flow rate was set at 300 $\mu \mathrm{mol} \cdot \mathrm{m}^{-2} \cdot \mathrm{s}^{-1}$ on the reference side. The $\mathrm{CO}_{2}$ concentration was set at $400 \mu \mathrm{mol} \cdot \mathrm{mol}^{-1}$ with a $\mathrm{CO}_{2}$ mixer and a $\mathrm{CO}_{2}$ tank. By setting $P A R$ at the "tracking" option of the LI-6400, the $P A R$ value inside the measurement chamber was similar to that of the plants under each shading treatment. Measurements were conducted in developed plants on clear days (unshaded conditions $P A R$ greater than $1900 \mu \mathrm{mol} \cdot \mathrm{m}^{-2} \cdot \mathrm{s}^{-1}$ ) at 1200 to $1500 \mathrm{HR}$ Eastern Standard Time in 2009 (11 and 20 Aug., 8 Sept., and 1 Oct.) and 2010 (28 and 30 July and 12 Aug.) using two developed and fully exposed leaves per experimental plot.

Leaf mineral nutrients. Leaf samples (20 fully developed leaves from new growth) from developed plants were dried at $70{ }^{\circ} \mathrm{C}$ for $2 \mathrm{~d}$ and analyzed for mineral nutrient concentration at the Univ. of Georgia Agricultural \& Environmental Services Laboratories, Athens, GA.

Statistical analysis. Data were analyzed using the General Linear Model and Regression Procedures from SAS (SAS Version 9.3; SAS Inst. Inc., Cary, NC). Data means were separated by Fisher's protected least significant difference test at $95 \%$ confidence. Percentages were transformed to arsine values before analysis. For clarity, non-transformed percentage means were used for presentation in tables and figures. Data from all years were pooled if no year $\times$ treatment interactions were found.

\section{Results and Discussion}

Microenvironment. Maximal, minimal, and mean air temperatures and rainfall during the growing seasons in 2009 and 2010 are shown in Figure 1. Midday $P A R$, midday $\mathrm{T}_{\text {leaf }}$, mean $\mathrm{T}_{\text {air }}$, and mean RZT decreased with increased shading levels (Fig. 2). Mean PAR values were similar over the season in both years (data not shown). Mean $\mathrm{T}_{\text {air }}$ was $0.5^{\circ} \mathrm{C}$ lower, midday $\mathrm{T}_{\text {leaf }}$ was $2.7^{\circ} \mathrm{C}$ lower, and RZT was $2.6{ }^{\circ} \mathrm{C}$ lower at $80 \%$ shading compared with unshaded conditions. $P A R$ and $\mathrm{T}_{\text {leaf }}$ were not different among cultivars (data not shown).

Our results are consistent with previous reports that show that shading reduces solar radiation, $\mathrm{T}_{\text {air }}, \mathrm{RZT}$, and $\mathrm{T}_{\text {leaf }}$ (Allen, 1975; Kittas et al., 2009; Smith et al., 1984; Valli et al., 1965; Zhang, 2006). In Israel, a 30\% black shading screen was found to reduce solar radiation and wind speed but did not significantly alter maximum daily air temperature and vapor pressure deficit compared with open field conditions (Moller and Assouline, 2007). The optimal $T_{\text {air }}$ range for pepper is 20 to $25^{\circ} \mathrm{C}$ (Rubatzky and Yamaguchi, 1999; Wien, 1997), whereas the optimal RZT range under field conditions is 25 to $27.5^{\circ} \mathrm{C}$ (DíazPérez, 2010). High values of seasonal $\mathrm{T}_{\text {air }}$, midday $\mathrm{T}_{\text {leaf, }}$, and seasonal RZT (Fig. 2) suggest that bell pepper plants were under heat stress, particularly those that were unshaded. Root zone temperature under plastic mulch affects plant growth and yield in several vegetable crops (Díaz-Pérez et al., 2008). Root zone temperature is affected by the amount of heat retained by the plastic mulch, which is determined by the optical properties of the mulch (Lamont, 2005). Root zone temperature increases with increased solar radiation and decreases with increased shading as that caused by plant canopy cover (Díaz-Pérez et al., 2005). In some circumstances, like when there is poor ventilation inside the shade house, shading nets may increase $\mathrm{T}_{\text {air }}$ (Castellano et al., 2008). In this study, however, the relatively small shading structures used allowed for air circulation that probably reduced presence of $\mathrm{T}_{\text {air }}$ gradients under shade.

Soil water content. Soil water content increased with increased shade levels in all cultivars (Fig. 3). Possibly, shading reduced evaporative demand and caused reduced transpiration, resulting in decreased soil water uptake by bell pepper (Allen, 1975; Kittas et al., 2009; Moller et al., 2004; Valli et al., 1965). In unmulched soil, shading could also reduce soil evaporation. A $30 \%$ black shading net reduced solar radiation, wind speed, and water requirements and increased irrigation water use efficiency in bell pepper (Moller and Assouline, 2007). Similarly, in greenhouse-grown tomato (Solanum lycopersicum L.), crop water use decreased and water use efficiency increased with shade level (Gent, 2008).

Plant growth. Plant height, plant leaf area, individual leaf area, individual leaf DW, and LWR (fraction of total aboveground biomass allocated to leaves) increased with increased shade level, whereas number of leaves per plant and SLW (leaf weight per unit leaf area; it is an estimator of leaf thickness) decreased with increased shade level (Fig. 4). Leaf, stem, and vegetative top dry weights were not significantly different among shade levels. Among cultivars, individual leaf DW was highest ( $P<0.05$ ) for 'Stiletto' $(236 \mathrm{mg} / \mathrm{leaf})$ followed by 'Sirius' (189 mg/leaf), 'Lafayette' (188 mg/leaf), and 'Camelot' (212 mg/leaf). Leaf weight ratio was highest $(P<0.05)$ for
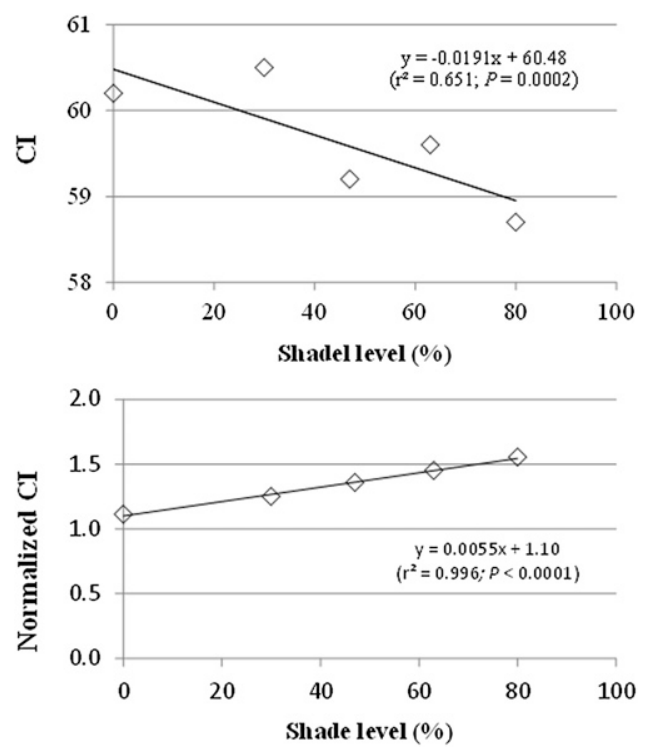

Fig. 5. Chlorophyll indices (CIs) and normalized CI (CI divided by their respective specific leaf weight) as function of shade level in bell pepper. Data from cultivars Camelot, Lafayette, Sirius, and Stiletto were pooled, Tifton, GA, Spring of 2009 and 2010. 
'Lafayette' (0.446) followed by 'Stiletto' (0.426), 'Sirius' (0.403), and 'Camelot' (0.397). Leaf, stem, and vegetative top DWs, stem diameter, plant leaf area, leaf number per plant, individual leaf area, and SLW were similar among cultivars. There were no shade-by-cultivar interactions for any of the plant growth variables.

Under low light, plants undergo morphological changes to maximize light use. Plants adapted to shade have greater foliar surface and specific leaf area, thinner leaves, and taller stems compared with plants adapted to strong light (Larcher, 1995). Our results agree with studies showing that shaded peppers have longer internodes, larger leaves, greater whole-plant leaf area, and thinner leaves (i.e., lower SLW) (Duggar, 1903; Kittas et al., 2009; Young, 1961). Results are also consistent with a bell pepper study under high-light field conditions in Israel, in which plant height, number of nodes, and leaf area increased with increased shade level (Rylski and Spigelman, 1986). Changes in bell pepper plant growth [augmented leaf biomass, leaf area, and plant height at the expense of fruit biomass (unpublished data)] habit and increased LWR with increased shading indicate that plants underwent modifications in the allocation of assimilates, resulting in maximized light interception under shaded conditions.

Under shaded conditions, plants had thinner leaves, as indicated by their lower SLW values. A $40 \%$ shade level in tomato reduced SLW by $24 \%$ compared with unshaded plants (Bertin and Gary, 1998). Similarly, in pepper, the $47 \%$ shade level resulted in a $19 \%$ reduction in SLW. The energetic cost for the plant to produce a given leaf area is lower when shaded (Larcher, 1995). Stems in shaded plants were thinner and presumably less lignified than those under higher light conditions, although stem biomass was unaffected. Stem diameter is related to upper plant DW, leaf area, and the ability of plants to transport water from the soil to leaves (Larcher, 1995). Increased plant leaf area with increased shading was associated with a reduced number of leaves per plant. In several species, specific leaf area (inverse of SLW) and chlorophyll concentration increase with increased shading (Björkman, 1981).

Leaf chlorophyll index. Chlorophyll indices decreased with increased shading levels (Fig. 5) and were not correlated with leaf $\mathrm{N}$ concentration. Chlorophyll indices were highest $(P<0.0001)$ in 'Camelot' (mean =
60.7) followed by 'Lafayette' ( $m e a n=59.8)$ and 'Stiletto' (mean $=59.5)$ and lowest in 'Sirius' (mean $=58.4$ ). In general, leaves adapted to low light have larger chloroplast size and greater chlorophyll content per chloroplast than leaves adapted to strong light (Larcher, 1995). Chlorophyll indices have been used as indirect estimators of chlorophyll and leaf $\mathrm{N}$ concentrations (Liu
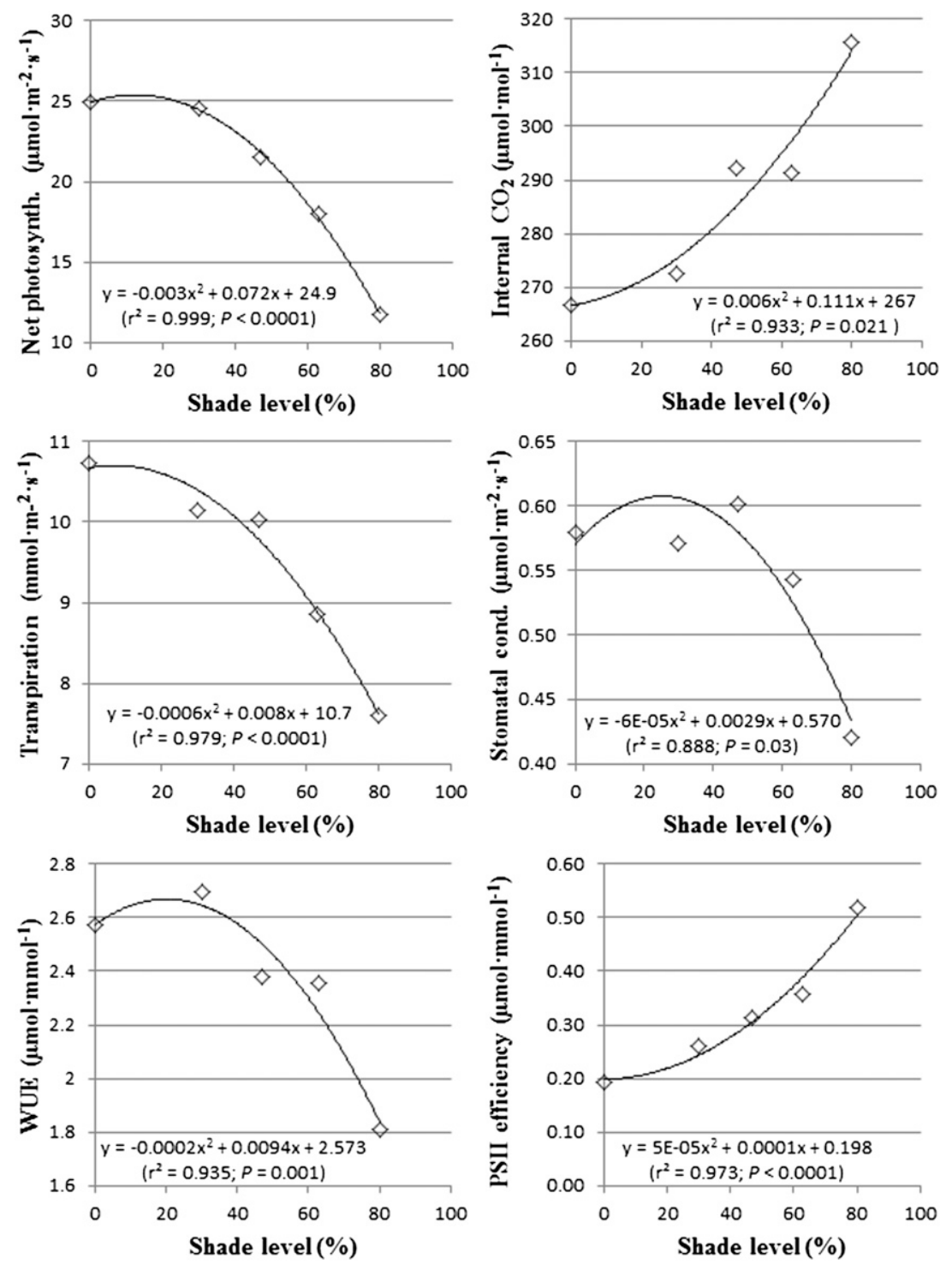

Fig. 6. Net photosynthesis, internal $\mathrm{CO}_{2}$ concentration, transpiration, stomatal conductance $\left(g_{\mathrm{S}}\right)$, water use efficiency (WUE), and photosystem II (PSII) efficiency in bell pepper as affected by shade level. Data from cultivars Camelot, Lafayette, Sirius, and Stiletto were pooled, Tifton, GA, Spring of 2009 and 2010.

Table 1. Leaf gas exchange variables and photosynthesis II (PSII) efficiency in bell pepper as affected by cultivar, Tifton, GA, Spring-Summer of 2009 and $2010 .^{z}$

\begin{tabular}{|c|c|c|c|c|c|c|}
\hline Cultivar & $\begin{array}{c}\text { Net photosynthesis } \\
\left(\mu \mathrm{mol} \cdot \mathrm{m}^{-2} \cdot \mathrm{s}^{-1}\right)\end{array}$ & $\begin{array}{l}\text { Internal } \mathrm{CO}_{2} \\
\left(\mu \mathrm{mol} \cdot \mathrm{mol}^{-1}\right)\end{array}$ & $g_{\mathrm{S}}\left(\mathrm{mol} \cdot \mathrm{m}^{-2} \cdot \mathrm{s}^{-1}\right)$ & $\begin{array}{l}\text { Transpiration } \\
\left(\mathrm{mmol} \cdot \mathrm{m}^{-2} \cdot \mathrm{s}^{-1}\right)\end{array}$ & $\begin{array}{l}\text { Water use efficiency } \\
\left(\mu \mathrm{mol} \cdot \mathrm{mmol}^{-1}\right)\end{array}$ & $\begin{array}{l}\text { PSII efficiency } \\
\left(\mu \mathrm{mol} \cdot \mathrm{mmol}^{-1}\right)\end{array}$ \\
\hline Lafayette & $19.8 \mathrm{~b}$ & $283 \mathrm{~b}$ & 0.565 & 9.28 & 2.39 & 0.304 \\
\hline Sirius & $19.5 \mathrm{~b}$ & $288 \mathrm{ab}$ & 0.625 & 9.52 & 2.36 & 0.315 \\
\hline Significance & ****x & $*$ & NS & NS & NS & NS \\
\hline
\end{tabular}

${ }^{2}$ Leaf gas exchange measurements $(\mathrm{n}=$ two plants/experimental plot) conducted on 11 and 20 Aug., 8 Sept., and 1 Oct. 2009 and 28 and 30 July and 12 Aug. 2010.

${ }^{y}$ Means followed by the same letter in a column are not significantly different based on Fisher's protected least significant difference test $(P \leq 0.05)$.

${ }_{\mathrm{NS}}, *, * *$ Nonsignificant or significant at $P<0.05$, and 0.001 , respectively.

$g_{\mathrm{S}}=$ stomatal conductance. 
Chlorophyll indices were normalized by dividing them by their respective SLW. Normalized CI increased with increased shade level (Fig. 4) and increased quadratically with leaf $\mathrm{N}$ concentration $\left(r^{2}=0.867 ; P=\right.$ 0.001 ). Our results are consistent with those of Peng et al. (1993) in rice (Oryza sativa L.) and indicated that $\mathrm{CI}$ in bell pepper leaves should be normalized by SLW when comparing leaves differing in thickness such as leaves from different developmental stages or leaves grown in dissimilar light environments. Another possible cause for the low correlation between $\mathrm{CI}$ and leaf $\mathrm{N}$ is that values greater than 50 may be less accurate for the chlorophyll meter used. Possibly, the reduced accuracy is related to increased leaf thickness. In woody ornamentals with thick leaves, the Chlorophyll Meter SPAD-502 (Minolta Co., Ltd., Ramsey, NJ) also gave $\mathrm{CI}$ that were unrelated with leaf $\mathrm{N}$ concentration (Ruter, personal communication).

Leaf gas exchange. Net photosynthesis, transpiration, $g_{\mathrm{S}}$, and water use efficiency decreased quadratically and internal $\mathrm{CO}_{2}$ concentration and PSII efficiency increased quadratically with increased shade level (Fig. 6). Net photosynthesis and $g_{\mathrm{S}}$ were relatively unaffected at $30 \%$ to $47 \%$ shade level or lower. There was a linear relationship between net photosynthesis and $g_{\mathrm{S}}(\mathrm{y}=8.72 \mathrm{x}+11.6$; $\left.r^{2}=0.362 ; P<0.0001\right)$. Net photosynthesis was highest in 'Camelot' and lowest in "Lafayette' and 'Sirius' and internal $\mathrm{CO}_{2}$ concentration was highest in 'Stiletto' and lowest in 'Lafayette' (Table 1). Stomatal conductance, transpiration, water use efficiency, and PSII efficiency were similar among cultivars. There were no date $x$ shade interactions.

Moderate shading levels resulted in reduced leaf temperature and leaf transpiration without reducing net photosynthesis. This reduced leaf transpiration was likely attributed to reduced evaporative demand and probably explains the increased soil water content and reduced plant water uptake under shaded conditions. The linear relationship between net photosynthesis and $g_{\mathrm{S}}$ suggests that stomatal control of photosynthesis was substantial under shade. The increased internal $\mathrm{CO}_{2}$ concentration with increased shade level also suggests, however, that there were also non-stomatal factors such as mesophyll or biochemical factors, limiting net photosynthesis (Assmann, 1988).

To our knowledge, there are no reports on leaf gas exchange in bell pepper as affected by shade levels under field conditions. The ecophysiological literature has numerous reports on differences in functional characteristics between sun and shade leaves. In general, sun leaves have greater photosystem activity, speed of electron transport, quantum yield, carboxylation efficiency, and photosynthetic capacity compared with shade leaves (Larcher, 1995). In soybean (Glycine
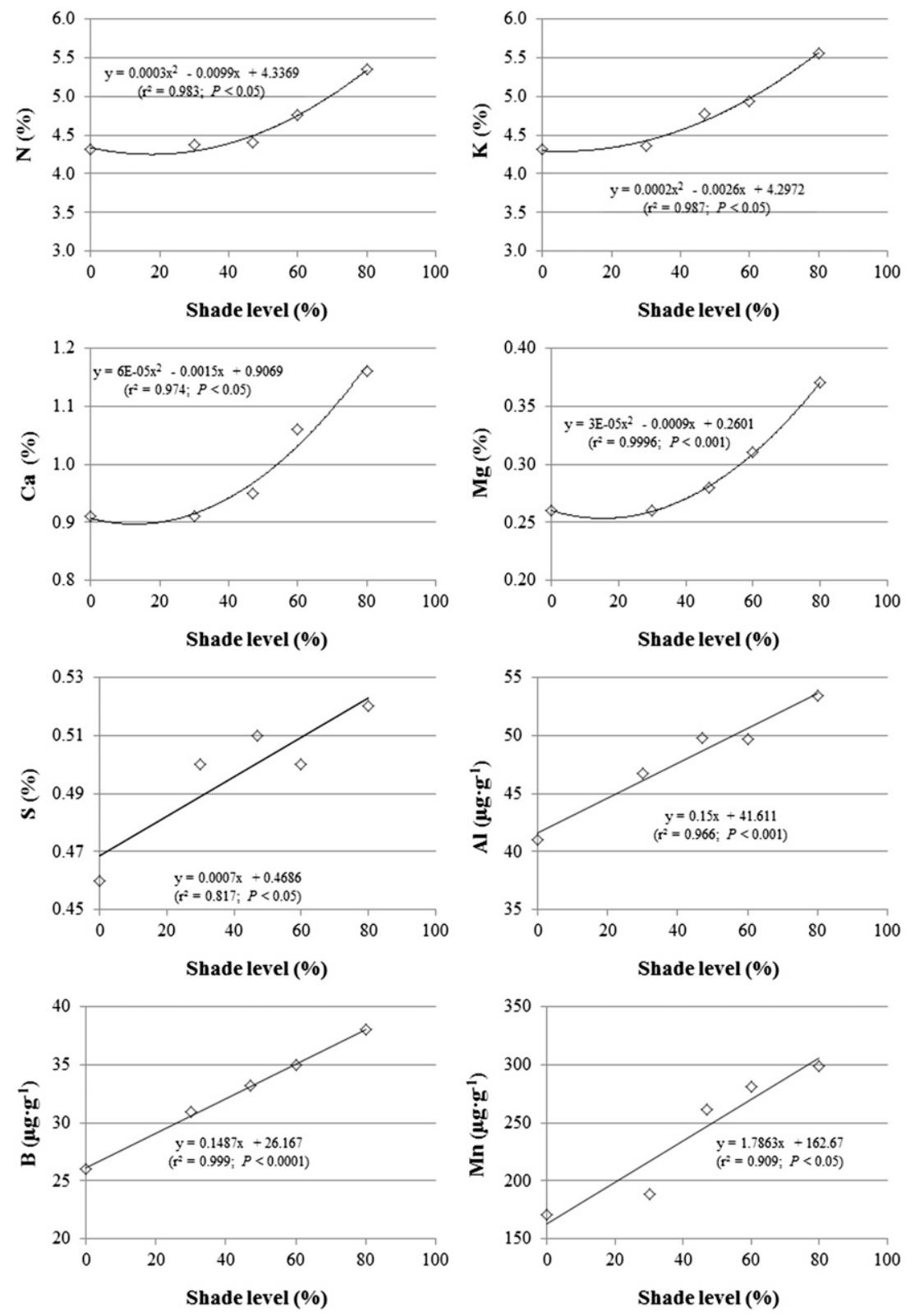

Fig. 7. Leaf mineral nutrient composition of mature bell pepper as affected by shade level. Data from cultivars Camelot, Lafayette, Sirius, and Stiletto were pooled, Tifton, GA, Spring of 2009 and 2010.

Table 2. Leaf mineral nutrient concentrations in four cultivars of mature bell pepper plants grown in the field, Tifton, GA, Spring-Summer of 2009 and $2010{ }^{2}$

\begin{tabular}{|c|c|c|c|c|c|c|c|c|c|c|c|c|c|c|c|}
\hline & $\mathrm{N}$ & $\mathrm{P}$ & $\mathrm{K}$ & $\mathrm{Ca}$ & $\mathrm{Mg}$ & $\mathrm{S}$ & $\mathrm{Al}$ & B & $\mathrm{Cu}$ & $\mathrm{Fe}$ & $\mathrm{Mn}$ & Mo & $\mathrm{Na}$ & $\mathrm{Ni}$ & $\mathrm{Zn}$ \\
\hline & \multicolumn{6}{|c|}{ 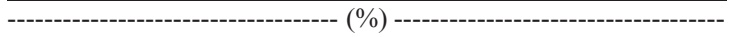 } & \multicolumn{9}{|c|}{ 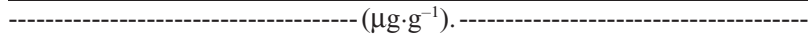 } \\
\hline Camelot & $4.67 \mathrm{a}^{\mathrm{z}}$ & $0.30 \mathrm{a}$ & $4.81 \mathrm{ab}$ & $1.06 \mathrm{a}$ & $0.28 \mathrm{c}$ & $0.49 \mathrm{~b}$ & 50 & $34 \mathrm{a}$ & 89 & 160 & 263 & 2.6 & 36 & 2.8 & $94 \mathrm{a}$ \\
\hline Lafayette & $4.64 \mathrm{a}$ & $0.31 \mathrm{a}$ & $4.85 \mathrm{a}$ & $1.06 \mathrm{a}$ & $0.34 \mathrm{a}$ & $0.52 \mathrm{a}$ & 47 & $32 \mathrm{ab}$ & 87 & 156 & 233 & 2.5 & 36 & 2.8 & $82 \mathrm{~b}$ \\
\hline Sirius & $4.78 \mathrm{a}$ & $0.29 \mathrm{a}$ & $4.90 \mathrm{a}$ & $0.88 \mathrm{~b}$ & $0.30 \mathrm{~b}$ & $0.51 \mathrm{ab}$ & 46 & $35 \mathrm{a}$ & 91 & 160 & 236 & 2.6 & 39 & 2.6 & $79 \mathrm{bc}$ \\
\hline Stiletto & $4.49 \mathrm{~b}$ & $0.26 \mathrm{~b}$ & $4.62 \mathrm{~b}$ & 0.99 a & $0.26 \mathrm{c}$ & $0.49 \mathrm{~b}$ & 50 & $29 \mathrm{~b}$ & 90 & 156 & 234 & 2.5 & 36 & 2.4 & $72 \mathrm{c}$ \\
\hline Significance & $* * * \mathrm{y}$ & $* * * *$ & $*$ & $* * * *$ & $* * * *$ & $*$ & NS & $* *$ & NS & NS & NS & NS & NS & NS & $* * * *$ \\
\hline
\end{tabular}

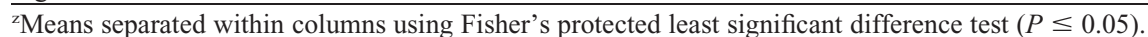

$\mathrm{y}_{\mathrm{NS}}, * * * * * * *, * *, *$ Nonsignificant or significant at $P \leq 0.0001, P \leq 0.001, P \leq 0.01$, or $P \leq 0.05$, respectively. 
displayed an increased water use efficiency compared with exposed trees (Alarcon et al., 2006). The reduced transpiration and maintenance of photosynthesis in shaded plants compared with exposed trees indicated that use of screen structures in semiarid environments could help reduce plant water stress and increase water use efficiency (Barradas et al., 2005).

Leaf mineral nutrients. Leaf concentrations of $\mathrm{N}, \mathrm{K}, \mathrm{Ca}, \mathrm{Mg}, \mathrm{S}, \mathrm{Al}, \mathrm{B}$, and $\mathrm{Mn}$ increased with increased shading levels for the majority of nutrients, although the concentrations changed little below 30\% shade for $\mathrm{K}, \mathrm{Ca}$, and $\mathrm{Mg}$ or $47 \%$ shade for $\mathrm{N}$ (Fig. 7). Mineral nutrients, however, varied in degree of increase with shading ranging from as low as $7 \%$ in $\mathrm{P}$ to $75 \%$ in $\mathrm{Mn}$. Leaf concentrations of $\mathrm{P}$, copper, iron, Mn, molybdenum, sodium, nickel, and zinc $(\mathrm{Zn})$ did not show either linear or quadratic relationships with shade level. Among cultivars, 'Stiletto' had the lowest leaf concentrations of $\mathrm{N}, \mathrm{P}, \mathrm{K}, \mathrm{Mg}, \mathrm{B}$, and $\mathrm{Zn}$ (Table 2). There were few differences among cultivars for the other mineral nutrients. The differences in concentrations among cultivars were relatively small for most mineral nutrients.

There are a limited number of studies on mineral nutrient uptake and accumulation by vegetable crops as affected by shading. The increased foliar nutrient concentrations observed in our study in response to shading are consistent with reports on tomato showing that shading increases foliar concentration of N, P, and K (Liu et al., 2003), plant N concentration and dry mass partitioning to roots (de Groot et al., 2002), and N and K uptake (Gent, 2008). Increased foliar $\mathrm{N}$ concentration in shaded plants has been associated with increased leaf chlorophyll concentration, a plant response intended to increase light capture under shaded conditions (de Groot et al., 2002).

Shading possibly resulted in increased mineral nutrient concentrations in shaded leaves by modifying temperature conditions. Reductions in $\mathrm{T}_{\text {air }}$ and RZT associated with shading allowed for amelioration of heat stress that might have resulted in increased mineral nutrient uptake. Previous studies in tomato in solution culture indicated that the optimal temperature for uptake of the majority of mineral nutrients and plant growth responses is $25{ }^{\circ} \mathrm{C}$ (Tindall et al., 1990). It may be that heat stress amelioration by shading benefited bell pepper plant growth indirectly by modifying the crop thermal environment so as to be more favorable for mineral nutrient uptake.

In conclusion, morphological changes such as taller plants and thinner and larger leaves likely enhanced light capture under shaded conditions compared with unshaded plants. High shade levels reduced leaf temperature and excessive leaf transpiration but resulted in reduced leaf photosynthesis. Thus, moderate shade levels (30\% and $47 \%$ ) were the most favorable for bell pepper plant growth and function.

\section{Literature Cited}

Alarcón, J.J., M.F. Ortuno, E. Nicolás, A. Navarro, and A. Torrecillas. 2006. Improving water-use efficiency of young lemon trees by shading with aluminised-plastic nets. Agr. Water Mgt. 82:387-398.

Allen, L.H., Jr. 1975. Shade-cloth microclimate of soybeans. Agron. J. 67:175-181.

Assmann, S.M. 1988. Stomatal and non-stomatal limitations to carbon assimilation: An evaluation of the path-dependent method. Plant Cell Environ. 11:577-582.

Barradas, V.L., E. Nicolas, A. Torrecillas, and J.J. Alarcon. 2005. Transpiration and canopy conductance in young apricot (Prunus armenica L.) trees subjected to different PAR levels and water stress. Agr. Water Mgt. 77:323333

Bertin, N. and C. Gary. 1998. Short and long term fluctuations of the leaf mass per area of tomato plants - Implications for growth models. Ann. Bot. (Lond.) 82:71-81.

Björkman, O. 1981. Response to different quantum flux densities, p. 57-107. In: Lange, O.L., P.S Nobel, C.B. Osmond, and H. Ziegler (eds.). Physiological plant ecology. Responses to the physical environment. Springer-Verlag, Berlin, Germany.

Boyhan, G., J. Díaz-Pérez, C. Riner, R. Hill, and D. Thigpen. 2008. Evaluation of bell pepper and tomato varieties with and without shade. HortScience 43:1256.

Castellano, S., G.S. Mugnozza, G. Russo, D. Briassoulis, A. Mistriotis, S. Hemming, and D. Waaijenberg. 2008. Plastics net in agriculture: A general review of types and applications. Appl. Eng. Agr. 24:799-808.

de Groot, C.C., L.F.M. Marcelis, R. van den Boogaard, and H. Lambers. 2002. Interactive effects of nitrogen and irradiance on growth and partitioning of dry mass and nitrogen in young tomato plants. Funct. Plant Biol. 29: 1319-1328.

Deli, J. and H. Tiessen. 1969. Interaction of temperature and light intensity on flowering of Capsicum frutescens var. grossum cv. California Wonder. J. Amer. Soc. Hort. Sci. 40: 493-497.

Díaz-Pérez, J.C. 2010. Bell pepper (Capsicum annum L.) grown on plastic film mulches: Effects on crop microenvironment, physiological attributes, and fruit yield. HortScience 45:1196-1204.

Díaz-Pérez, J.C., S.C. Phatak, D. Giddings, D. Bertrand, and H.A. Mills. 2005. Root zone temperature, plant growth, and fruit yield of tomatillo as affected by plastic film mulch. HortScience 40:1312-1319.

Díaz-Pérez, J.C., S. Phatak, and J. Silvoy. 2008. Plastic film mulches as a means to modify rootzone temperature and improve crop performance, p. 331-346. In: Stevens, C. and V.A. Khan (eds.). Recent advances in agriculture. Research Signpost, Kerela, India.

Dorland, R.E. and F.W. Went. 1947. Plant growth and controlled conditions. VIII. Growth and fruiting of the chili pepper (Capsicum annuит). Amer. J. Bot. 34:393-401.

Duggar, B.M. 1903. The physiological effects of shading plants. Proc. Amer. Soc. Hort. Sci. $1: 15-17$.

El-Aidy, F., M. El-Afry, and F. Ibraheim. 1993. Effect of shade and fertilizer levels and their interaction on fruit yield of sweet pepper. Acta Agron. Hung. 42:59-67.

Evans, G.C. 1972. The quantitative analysis of plant growth. Blackwell Scientific, Oxford, UK.
Gent, M.P.N. 2008. Density and duration of shade affect water and nutrient use in greenhouse tomato. J. Amer. Soc. Hort. Sci. 133:619627.

Ilic, Z.S., L. Milenkovic, L. Stanojevic, D. Cvetkovic, and E. Fallik. 2012. Effects of the modification of light intensity by color shade nets on yield and quality of tomato fruits. Sci. Hort. 139:9095.

Kittas, C., N. Katsoulas, N. Rigakis, T. Bartzanas, and E. Kitta. 2012. Effects on microclimate, crop production and quality of a tomato crop grown under shade nets. J. Hort. Sci. Biotechnol. 87:7-12.

Kittas, C., N. Rigakis, N. Katsoulas, and T. Bartzanas. 2009. Influence of shading screens on microclimate, growth and productivity of tomato. Acta Hort. 807:97-102.

Lamont, W.J. 2005. Plastics: Modifying the microclimate for the production of vegetable crops. HortTechnology 15:477-481.

Larcher, W. 1995. Physiological plant ecology. Ecophysiological and stress physiology of functional groups. Springer, Berlin, Germany.

Li, J.W., J.P. Yang, D.S. Li, P.P. Fei, T.T. Guo, C.S. Ge, and W.Y. Chen. 2011. Chlorophyll meter's estimate of weight-based nitrogen concentration in rice leaf is influenced by leaf thickness. Plant Prod. Sci. 14:177-183.

LI-COR. 2003. Using the LI-6400. Portable Photosynthesis System. Book 5. Leaf Chamber Fluorometer. LI-COR Biosciences, Inc., Lincoln, NE.

Liu, X.Z., S.Z. Kang, H.P. Yi, and J.H. Zhang. 2003. Dry-matter partitioning, yield and leaf nutrient contents of tomato plants as influenced by shading at different growth stages. Pedosphere 13:263-270

Liu, Y.J., Y.P. Tong, Y.G. Zhu, H. Ding, and E.A. Smith. 2006. Leaf chlorophyll readings as an indicator for spinach yield and nutritional quality with different nitrogen fertilizer applications. J. Plant Nutr. 29:1207-1217.

Madeira, A.C. and A. de Varennes. 2005. Use of chlorophyll meter to assess the effect of nitrogen on sweet pepper development and growth. J. Plant Nutr. 28:1133-1144.

Möller, M. and S. Assouline. 2007. Effects of a shading screen on microclimate and crop water requirements. Irrig. Sci. 25:171-181.

Möller, M., J. Tanny, Y. Li, and S.T. Cohen. 2004. Measuring and predicting evapotranspiration in an insect-proof screenhouse. Agr. For. Meteorol. 127:35-51.

Olle, M. and I. Bender. 2009. Causes and control of calcium deficiency disorders in vegetables: A review. J. Hort. Sci. Biotechnol. 84:577-584.

Peng, S.B., F.V. Garcia, R.C. Laza, and K.G. Cassman. 1993. Adjustment for specific leaf weight improves chlorophyll meters estimate of rice leaf nitrogen concentration. Agron. J. 85:987-990.

Roberts, B.W. and J.A. Anderson. 1994. Canopy shade and soil mulch affect yield and solar injury of bell pepper. HortScience 29:258 260.

Rubatzky, V.E. and M. Yamaguchi. 1999. World Vegetables: Principles, production, and nutritive values. Aspen Publishers, Inc., Gaithersburg, MD.

Russo, V.M. 1993. Shading of tomato plants inconsistently affects fruit yield. HortScience 28: 1133.

Rylski, I. and M. Spigelman. 1986. Effect of shading on plant development, yield and fruit quality of sweet pepper grown under conditions of high temperature and radiation. Sci. Hort. 29:31-35. 
Smith, I.E., M.J. Savage, and P. Mills. 1984 Shading effects on greenhouse tomatoes and cucumbers. Acta Hort. 148.

Taylor, M.D. and S.J. Locascio. 2004. Blossomend rot: A calcium deficiency. J. Plant Nutr. 27:123-139.

Tindall, J.A., H.A. Mills, and D.E. Radcliffe. 1990. The effect of root zone temperature on nutrient uptake of tomato. J. Plant Nutr. 13:939-956.
Tremblay, N., E. Fallon, and N. Ziadi. 2011 Sensing of crop nitrogen status: Opportunities, tools, limitations, and supporting information requirements. HortTechnology 21: 274-281.

Valli, V., J.H.H. Bryan, and H.W. Young. 1965 The effect of shade on the bio-climate and production of vegetable crops. Fla. State Hort. Soc. Proc. 78:95-101.
Wien, H.C. 1997. Peppers, p. 259-293. In: Wien, H.C. (ed.). The Physiology of vegetable crops. CAB International, Ithaca, NY.

Young, H.W. 1961. Production of spring vegetables under shade. Fla. State Hort. Soc. Proc. 74:209-216.

Zhang, Z.B. 2006. Shading net applications in protected vegetable production in China. Acta Hort. 719:479-482. 